\title{
Gender and Student Participation
}

\author{
Bethany C. Leraas \\ Concordia College \\ Nicole R. Kippen \\ Concordia College \\ Susan J. Larson \\ Concordia College \\ larson@cord.edu
}

\begin{abstract}
Active class participation has been associated with student engagement and can be an important aspect of a successful learning experience in college classrooms. Several factors influence student participation including classroom dynamics (such as classroom connectedness, instructor-student rapport) and individual characteristics (such as biological sex and psychological gender). With respect to individual characteristics, previous research has evaluated sex differences in participation and has yielded inconsistent findings. The present study investigated the relationship between psychological gender and student participation both in- and out-of-class. Classroom connectedness and professorstudent rapport were assessed as possible moderating factors. Results indicated that masculinity and androgyny were associated with more in-class participation while femininity and androgyny were associated with student professor interaction outside of class. While both classroom connectedness and instructor-student rapport were correlated with student participation, there was no evidence of them moderating the relationship between gender and participation. Professor gender type was not associated with student participation. Implications for college classrooms and higher education are discussed.
\end{abstract}

Keywords: student participation, gender, sex, rapport, connectedness

Creating learning environments in which students are actively engaged in their learning has become a priority for educational institutions of all types, as evidenced by universities and colleges throughout the US regularly administering the National Survey on Student Engagement (NSSE) to capture the engagement of their students. One motivation for understanding student engagement is that it has been linked to college retention; for example, Svanum and Bigatti (2009) found that students who were highly engaged were 1.5 times more likely to complete a degree. Furthermore, these students, on average, required one fewer semester to complete their degree.

There are a variety of ways to facilitate student engagement, including by offering high impact practices such as undergraduate research, capstone courses, and cooperative education (Kuh, 2008). Professors can also impact engagement by making changes to their courses to address the cognitive, behavioral and emotional components (Fredrick, Blumenfeld \& Paris, 2004) of engagement. Oral participation is most closely related to behavioral engagement and pedagogical practices as simple as expecting and rewarding oral participation may contribute to an engaged learning experience (Jones, 2008). Handelsman, Briggs, Sullivan \& Towler (2005) argued that 
there were four factors in student engagement - participation/interaction, skills, emotion, and performance - suggesting oral participation may be directly related to engagement.

Asking questions and making oral contributions to class has been demonstrated in several studies to have benefits for students. Research indicates that students who actively participated were more motivated (Frisby \& Myers, 2008; Junn, 1994), engage in more critical thinking (Garside, 1996), and show improvement in communication skills (Dancer \& Kamvounias, 2005). Although oral participation is not synonymous with engagement (Frymier \& Houser, 2016) Handelsman and colleagues (2005) conceptualized class participation as a subset of overall course engagement and found that participation significantly predicted midterm and final exam grades. The benefits of out-of-class interaction are also seen. According to a survey of 1,000 college graduates, individuals who had more interactions with professors outside of class were more likely to exhibit leadership qualities and to engage in volunteer or charity activities (Detweiler, 2016 as cited in EAB Daily Briefing, 2016).

Given the positive outcomes associated with participation, researchers have attempted to better understand class participation and to identify factors that encourage and hinder it. This is important as faculty often include student participation as a component of the course grade, especially in US higher education. Faculty, as well as researchers, often define participation as verbal contributions made during class time, however, Dancer and Kamvounias (2005) identified five categories of participation including preparation, contribution to discussion, group skills, communication skills, and attendance. Interactions with the professor outside of class including exchanging emails or meeting the professor in person to discuss class material (Weaver \& Qi, 2005) also contribute to student participation and overall engagement. Understanding these multiple categories of participation and identifying other factors that encourage and hinder participation are important to creating productive learning environments.

Much of the research on factors that encourage or hinder participation has focused on the professor's role in establishing an environment that facilitates student participation. Weaver and Qi (2005) found that interaction between the professor and student was the largest predictor of participation both in- and out-of-the classroom. Professor rapport, defined as "a mutual, trusting, and prosocial bond" (Frisby \& Martin, 2010 p. 147) has been investigated as one factor that influences student participation. Frisby and Martin found that perceived rapport with the professor predicted learning outcomes and participation. Others have shown that students who were more active participators had more favorable perceptions of their professor and were more likely to view their professor as positive, personalizing and engaging in more class discussion than students who were less active participators (Crombie, Pyke, Silverthorn, Jones, \& Piccinin, 2003). Conversely, when professors engage in behaviors that discourage rapport, such as ignoring students, being verbally aggressive, or being overly critical, student participation is lower (for review, see Rocca, 2010).

Other research has examined the role of the relationships among the students in the classroom in promoting student participation. Dwyer and colleagues (2004) conceptualized a connected classroom climate as "student-to-student perceptions of a supportive and cooperative communication environment in the classroom" (p. 267). In this type of environment, students are able to express themselves freely in the classroom without fear of judgment from peers. Fassinger $(1995,2000)$ examined factors that influenced student participation and found that classrooms with high levels of participation had students with more positive perceptions of the class dynamics, such as viewing peers as supportive and cooperative rather than as argumentative and competitive. A similar conclusion was reached by Frisby and Martin (2010) who found that a connected

Journal of the Scholarship of Teaching and Learning, Vol. 18, No. 4, December 2018. josotl.indiana.edu 
classroom climate and perceived classmate rapport was positively correlated with student participation. Classroom connectedness may also be a better predictor of student participation than other class factors. Sidelinger and Booth-Butterfield (2010) demonstrated that student involvement in the class was associated with positive perceptions of connectedness, regardless of class size. Taken together, the research indicates that a classroom environment where there is mutual respect and care between students and the professor (i.e. high degree of both classroom connectedness and rapport) is conducive to classroom participation and learning (Johnson, 2009; Rocca, 2010).

In addition to environmental (e.g., class size) and interpersonal (e.g., connectedness and rapport) factors variables such as sex, psychological gender, and personality might impact classroom participation. Considerable research has evaluated the relationship between sex of both the students and professor and student participation. When student sex is considered, research findings are mixed. Numerous studies have found that females participate less than male students (summarized in Fassinger, 1995 and Rocca, 2010). For example, Crombie and colleagues (2003) found that male students rated themselves as more active participators than female students. Additionally, male students reported significantly more and longer interactions with their professor than females. Crawford and MacLeod (1990) found that female students perceived themselves as participating less than their male peers. Furthermore, they discovered that females and males have different reasons for not participating. Female students were more likely to attribute their lack of participation to reasons such as their "ideas were not well-formulated," "did not know enough about the subject," or fear of "appearing unintelligent in front of classmates." Male students, on the other hand, were more likely to attribute their lack of participation to "have not done the assigned reading" or "comments might negatively affect grades" (Crawford \& MacLeod, 1990, p. 116). Despite these findings, other research has failed to show these sex differences (see Rocca, 2010), or found only limited sex differences, e.g., sex differences in types of questions asked (Pearson \& West, 1991).

The relationship between professor sex and student participation has also been explored, also with mixed results. Some research suggests that female professors were more successful at creating a classroom environment where both male and female students participated (Crawford \& MacLeod, 1990). On the other hand, Canada and Pringle (1995) found that mixed-sex classes taught by a female tended to have more professor-driven interactions than those taught by males. Still other studies find little or no impact of professor sex.

Inconsistencies in revealing sex difference may be due to method of data collection. Allan and Madden (2006) collected both quantitative and qualitative data from female college students, using close-ended questionnaires and focus groups. Using quantitative data, sex differences were found to be less common. Qualitative data revealed that female students report unsupportive behaviors from both male and female professors and male students and they reported a "chilly climate" (Hall \& Sandler, 1982) in the classroom, such as discouragement, invisibility, and questioning of competence, factors which might hinder female student participation.

While method of data collection might explain some of the inconsistency in the findings, it is noteworthy that nearly all studies conducted with students in the classroom have focused on the sex, rather than the psychological gender, of the students. Because of conflicting results on whether male students participate more in-class, we suggest that the psychological construct of gender, rather than biological sex, may be a more useful way to examine differences in student participation.

According to Bem (1974), gender is conceptualized on two dimensions, masculinity (including characteristics such as self-reliant, assertive, dominant and independent) and femininity

Journal of the Scholarship of Teaching and Learning, Vol. 18, No. 4, December 2018. josotl.indiana.edu 
(including characteristics such as affectionate, loyal, warm and soft-spoken), which produces four gender types: masculine (high masculinity), feminine (high femininity), androgynous (high masculinity and high femininity), or undifferentiated (low masculinity and low femininity). Because of the variety of traits they possess, Bem postulated that androgynous individuals would be the most adaptable. While some research does not support this notion (e.g. O'Heron \& Orlofsky, 1990), a robust body of literature does support that androgynous individuals fare better than other gender types. For example, it has been shown that androgynous individuals have higher selfesteem and more effective coping styles (Huang, Zhu, Zheng, Zhang, \& Shiomi, 2010) and more positive social development (Waterman \& Whitbourne, 1982) than other gender types. Because of their adaptability and other positive attributes, it is likely that androgynous individuals would thrive in a college environment.

Work by Pearson and West (1991) supports the hypothesis that masculine students will participate more in class than feminine students. Using the Personal Attributes Questionnaire to measure masculinity, they found that masculine students were more active participants in class (via asking questions) than feminine students. Given that male students may be, but are not always, more masculine than female students, when researchers find sex differences in participation it might actually be due to psychological gender. Pearson and West's work contributes to a small body of research that has evaluated intrapersonal traits, such as gender and personality (Capsi, Chajut, Saporta \& Beyth-Marom, 2006; Linvill, 2014; Furnham \& Medhrst, 1995) on student engagement and in-class participation. Their findings support the continued investigation of the role of intrapersonal traits on classroom participation.

Evaluation of professor intrapersonal traits has also suggested a role of gender in classroom participation. Basow $(2000 ; 2006)$ investigated traits of college professors that were valued or disliked by students and whether these preferences varied by professor or student gender type. Results indicated that professors rated as the "best" by students were more likely to be viewed as androgynous while the "worst" professors were more likely to be undifferentiated. Importantly, in Basow's studies, students rated professors gender type based on perceived traits of the professor; the professors did not complete the Bem inventory themselves, which is a more typical use of the instrument. Based on these studies by Basow and Pearson and West (1991), examining gender type may contribute to a better understanding participation in the college classroom than solely investigating biological sex.

We know from the vast body of literature, student participation in college classroom is affected by both environmental and interpersonal factors, such as classroom connectedness, professor-student rapport, and individual characteristics of sex and psychological gender. Since very little research has focused on psychological gender, the present study sought to investigate gender of both the professor and the student and its relationship with participation. Classroom connectedness and professor-student rapport were assessed as possible moderating factors. This study investigated the following questions:

Research Question (RQ)1: Is course participation related to sex (male/female) and psychological gender (masculinity, femininity, androgyny) of the student?

RQ2: Is course participation related to gender of the instructor?

RQ3: Is participation related to classroom connectedness (between students) and rapport (with professors)?

RQ4: Do connectedness and rapport moderate the relationship between gender and participation?

Journal of the Scholarship of Teaching and Learning, Vol. 18, No. 4, December 2018. 


\section{Method}

\section{Participants}

Participants were recruited from undergraduate classes at a small Midwestern liberal arts college after the midsemester break. Only classes that satisfied the college's general education curriculum and met during the 10:30-11:40 time slot on Mondays, Wednesdays, and Fridays were included, allowing for a wide range of disciplines, course levels, and students.

Out of the 51 classes contacted, 28 professors agreed to have their classes participate. These classes were from a variety of disciplines including biology, business, chemistry, communications, global studies, history, mathematics, music, nutrition and dietetics, philosophy, political science, religion, Scandinavian studies, sociology, and theatre art.

The participants consisted of 243 undergraduate students ranging in age from 18 to 30 years $(\mathrm{M}=19.78, \mathrm{SD}=1.44$ with $89 \%$ of the sample being $18-21$ years of age). Years in college ranged from 1 to 5 years or more, with $68.4 \%$ in their first or second year. Over two thirds of the students reported being female (male $=32.4 \%$, female $=67.6 \%, 2$ students did not report; current institutional enrollment is $58 \%$ female). Of the 243 students in our sample, 135 came from 16 courses in the spring semester; 105 were sampled from 12 courses in the fall semester. Three students took the survey in both semesters; data for only the first time they completed the survey are included in analyses. Table 1 includes the demographic breakdown for the fall and spring semester samples. Because there were no significant differences between the spring and fall semesters on psychological gender (data not shown) or demographic variables, datasets were combined for analyses.

Table 1. Demographic data for the spring semester and fall semester.

\begin{tabular}{|c|c|c|c|}
\hline & $\begin{array}{l}\text { Spring Semester } \\
N=135\end{array}$ & $\begin{array}{l}\text { Fall Semester } \\
N=105\end{array}$ & t-test \\
\hline Age of sample & & & $t(235)=-.03 \quad p=.97$ \\
\hline Mean Age (years) & 19.78 & 19.78 & \\
\hline Age Range (years) & $18-25$ & $18-30$ & \\
\hline$\%$ students $18-21$ years & $88.1 \%$ & $90.2 \%$ & \\
\hline Reported sex & & & $t(236)=1.03 p=.31$ \\
\hline Male & $29.6 \%$ & $35.2 \%$ & \\
\hline Female & $70.4 \%$ & $62.9 \%$ & \\
\hline Year in School & & & $t(235)=-1.95 p=.052$ \\
\hline First year & $39.3 \%$ & $25.7 \%$ & \\
\hline Second year & $31.1 \%$ & $38.1 \%$ & \\
\hline Third year & $13.3 \%$ & $7.6 \%$ & \\
\hline Fourth year & $15.7 \%$ & $25.7 \%$ & \\
\hline 5 years + & $.7 \%$ & $0.0 \%$ & \\
\hline
\end{tabular}

Note: Student's $t$ tests were conducted on the spring and fall semester data sets. There was a marginally significant effect of year in school. 


\section{Measures}

Student surveys: BSRI-S. The Bem Sex Role Inventory - Short Form (BSRI-S; Bem, 1974) determined the participant's psychological gender. The BSRI-S consisted of 30 items and participants were asked to rate how well the item applied to them using a seven-point Likert scale ( 1 = never true, 7 = always true). Recently, Bem's Sex Role inventory has been scored using a continuous scoring method to reveal scores for each individual on masculinity, femininity and androgyny, rather than create four gender types (Lemaster \& Strough, 2014; Strough, Leszczynski, Neely, Flinn, \& Margrett, 2007). Continuous scoring was utilized in this study to compute masculinity and femininity scores by totaling the masculine and feminine items and dividing by ten. Androgyny scores were calculated using the formula (BSRI Trait Masculinity + BSRI Trait Femininity) - |BSRI Trait Masculinity - BSRI Trait Femininity| (Strough et al.). Internal consistency analysis in our sample yielded a Cronbach's alpha of .86. Mean and standard deviation of gender and other variables, by sex of participant, are shown in Table 2.

Participation. Student in-class participation was defined as "any type of speaking up in class which is related to the class material (i.e. asking questions, making comments)" (Fassinger, 1995, Rocca, 2010, Weaver \& Qi, 2005). Adopted from various surveys including items used by Weaver and Qi (2005), six additional items inquired about interacting with the professor outside of class: (i) I see the professor when I have questions or problems with my coursework (ii) I exchange e-mails with the professor, (iii) I discuss various issues with the professor, (iv) I meet with the professor in less formal/social settings, (v) I obtain feedback from the professor before I submit an assignment for grading and (vi) my course instructor gives me personal feedback or appropriate coaching on what I am trying to learn. All items were measured on a self-report fivepoint scale $(1=$ almost never, $5=$ almost always $)$. The out-of-class communication behaviors were significantly correlated with one another and they were also correlated with reported levels of inclass participation (all ps., $<0.05$.). Other questions asked about class regulations regarding participation, such as "Is participation part of your grade in this class?" required a dichotomous yes or no answer.

Students in this study were asked to self-report their level of in-class participation. In an effort to evaluate whether this was a reliable measure of actual in-class participation, the researchers unobtrusively observed one three-hour evening class noting down each time a student made an oral contribution to the class. The students were then asked to self-report their in-class oral participation (defined as speaking up related to the class materials, such as asking questions or making comments) in two ways: estimating the number of times they participated and evaluating the frequency of their participation on a 5-point Likert scale. Pearson's $r$ correlations conducted on these data revealed significant correlations between observed participation and estimated number of comments $[r(18)=.95, p<0.001]$ and self-reported frequency of participation $[r(18)$ $=.84, p<0.001]$.

CCCI. The Connected Classroom Climate Inventory (CCCI) developed by Dwyer and colleagues (2004) was used to evaluate perceptions of student-student relationships. This inventory consisted of 18 items (e.g., the students in my class respect one another, the students in my class are supportive of one another $)$ that were rated on a five-point scale $(1=$ strongly disagree, $5=$ strongly agree). Analysis of the sample indicated that the CCCI is an internally reliable measure with a Cronbach's alpha of .92.

Rapport. Student rapport with the professor was assessed using two measures. The first (referred to as Rapport 1 in the results) was a modified version of Gremler and Gwinner's (2000)

Journal of the Scholarship of Teaching and Learning, Vol. 18, No. 4, December 2018. josotl.indiana.edu 
rapport scale used by Frisby and Myers (2008). Participants rated 11 items (e.g., I am comfortable interacting with my instructor, I look forward to seeing my instructor in class) on a seven-point scale $(1=$ strongly disagree, $7=$ strongly agree $)$. Internal consistency analysis for this measure revealed a Cronbach's alpha of. 94. A supplemental rapport measure (referred to as Rapport 2 in the results) was created from rapport-building behaviors identified by Webb and Barrett (2014). This inventory consisted of 13 items (e.g., my professor wants me to be successful in this class, my professor creates a classroom environment where I can speak openly) rated on a five-point scale $(1=$ strongly disagree, $5=$ strongly agree) that were related to professor behaviors (rather than more affective attitudes toward the professor). One item (my professor knows my name) required a dichotomous yes or no answer. Since all participants in our study reported that their professor knew their name this item was not included in analyses. Internal consistency analysis yielded a Cronbach's alpha value of .78.

Instructor Survey. Instructors of fall semester classes who participated completed the BSRI-S to determine their gender type. They also responded to a few demographic questions (not included in analyses).

\section{Procedure}

Procedures were approved by the institutional review board prior to commencing data collection. Professors of general education classes during the 10:30 MWF time period received an e-mail asking permission for the researcher to visit their class and inform their students of the project. Once permission was received, a researcher visited classes and collected the names and e-mail addresses of interested students so that a link to the survey could be sent to them. Students received an initial request to complete the on-line surveys as well one follow up reminder if they did not complete the surveys within two weeks. Professors also received an e-mail request and link to the instructor portion of the survey.

\section{Results}

Table 2 reports the sex differences for the three gender types (masculinity, femininity, and androgyny), connectedness and rapport.

\section{Biological sex of student and participation}

To assess RQ1, male and female students were compared on their in-class and out-of-class participation using independent samples $t$-tests. Male students reported participating more in the classroom than female students [Males: $\mathrm{M}=3.70, \mathrm{SD}=1.01,95 \% \mathrm{CI}[3.45,3.95$ ]; Females: $\mathrm{M}=3.35$ $\mathrm{SD}=1.15,95 \% \mathrm{CI}[3.18,3.52]$ and $t$ tests revealed that this effect was significant $[t(236)=2.31, p=$ 0.02]. Males and females did not differ in their reported out-of-class communications with professors. 
Table 2. Sex differences for self-reported in-class participation, gender type, connectedness and rapport.

\begin{tabular}{|c|c|c|c|c|c|c|c|c|c|c|c|c|c|c|}
\hline & \multicolumn{2}{|c|}{$\begin{array}{l}\text { Participation } \\
\text { in class }\end{array}$} & \multicolumn{2}{|c|}{ Masculinity } & \multicolumn{2}{|c|}{ Femininity } & \multicolumn{2}{|c|}{ Androgyny } & \multicolumn{2}{|c|}{ Connectedness } & \multicolumn{2}{|c|}{ Rapport 1} & \multicolumn{2}{|c|}{ Rapport 2} \\
\hline & $M$ & $S D$ & $M$ & $S D$ & $M$ & $S D$ & $M$ & $S D$ & $M$ & $S D$ & $M$ & $S D$ & $M$ & $S D$ \\
\hline Male & 3.70 & 1.01 & 4.71 & 0.83 & 5.13 & 0.91 & 8.93 & 1.56 & 65.30 & 9.08 & 53.27 & 11.32 & 56.33 & 4.82 \\
\hline Female & 3.35 & 1.15 & 4.66 & 0.87 & 5.49 & 0.92 & 8.93 & 1.60 & 66.08 & 9.41 & 54.52 & 11.90 & 54.52 & 5.32 \\
\hline
\end{tabular}

Note: $t$ test analyses revealed that males reported more participation in class than females $[t(236)$ $=2.31, p<0.01]$; males also scored significantly lower on femininity than females $[t(236)=2.81$, $p<0.01]$. No other sex differences were significant. $\mathrm{N}=105$ for connectedness and rapport variables, which was measured in the fall semester only; $\mathrm{N}=238$ for other variables listed.

\section{Psychological gender of student and participation.}

Pearson $r$ correlations were conducted to evaluate the relationship between class participation and gender type (RQ1). It was found that both masculinity and androgyny significant correlated with in-class participation. Femininity and androgyny were shown to be related to out-of-class interactions with the professor on a number of measures, such as exchanging e-mails and seeing the professor with questions. See Table 3 for all relevant correlations.

Table 3. The relationship between student masculinity, femininity and androgyny with inclass participation and out-of-class engagement with the professor.

\begin{tabular}{|c|c|c|c|}
\hline & Masculinity & Femininity & Androgyny \\
\hline $\begin{array}{l}\text { How frequently did you participate in class } \\
\text { this semester? }\end{array}$ & $.27 * *$ & .10 & $.30 * *$ \\
\hline 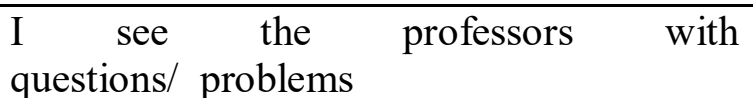 & .05 & $.27 * *$ & $.19 * *$ \\
\hline I exchange e-mail with the professor & .12 & $.29 * *$ & $.18^{* *}$ \\
\hline I discuss issues with the professor & .08 & $.19 * *$ & $.17 * *$ \\
\hline $\begin{array}{l}\text { I meet with the professor in informal } \\
\text { settings }\end{array}$ & $.15^{*}$ & .12 & $.16^{*}$ \\
\hline $\begin{array}{l}\text { I obtain feedback from the professor before } \\
\text { I submit an assignment }\end{array}$ & $.13^{*}$ & $.13 *$ & $.21 * *$ \\
\hline $\begin{array}{l}\text { My instructor gives me appropriate } \\
\text { coaching }\end{array}$ & .01 & $.18 * *$ & $.20 * *$ \\
\hline
\end{tabular}

Since analyses revealed that students from classes in which participation was graded reported higher levels of in-class participation [participation graded: $\mathrm{M}=3.62, \mathrm{SD}=1.06,95 \% \mathrm{CI}$ [3.45, 3.79]; participation not graded: $\mathrm{M}=3.12 \mathrm{SD}=1.17,95 \% \mathrm{CI}[2.88,3.36]$; $t(237)=3.31$, $p<0.01$ ], we also completed these analyses using a partial correlation controlling for required participation and all significant correlations reported in Table 3 remained significant. One 
additional correlation was significant: femininity was significantly correlated with seeing professors in informal settings when controlling for required class participation.

\section{Gender type of instructor}

With a subset of our participants $(n=105)$, we asked professors $(n=10)$ to complete the BSRI and we evaluated the relationship between professor gender and participation (in- and out-of-class, RQ2). Instructor's psychological gender was not significantly correlated with in-class or out-ofclass participation except for I exchange emails with the professor ( $p s .<0.05$ for masculinity, femininity and androgyny). Instructor gender was also not correlated with connectedness or either rapport measure. These correlations are reported in Table 4. Because class sizes differed $(\mathrm{M}=11.29, \mathrm{SD}=5.1)$ we ran these correlations controlling for class size. When doing so, professor femininity did not correlate with I exchange e-mail with the professor.

Table 4. The relationship between professor masculinity, femininity and androgyny with student in-class participation, out-of-class engagement, and ratings of connectedness and rapport.

\begin{tabular}{|c|c|c|c|}
\hline & $\begin{array}{l}\text { Professor } \\
\text { Masculinity }\end{array}$ & $\begin{array}{l}\text { Professor } \\
\text { Femininity }\end{array}$ & $\begin{array}{l}\text { Professor } \\
\text { Androgyny }\end{array}$ \\
\hline $\begin{array}{l}\text { How frequently did you participate in class } \\
\text { this semester? }\end{array}$ & -.12 & -.09 & -.14 \\
\hline $\begin{array}{l}\text { I see the professors with questions/ } \\
\text { problems }\end{array}$ & .02 & .18 & .08 \\
\hline I exchange e-mail with the professor & $.21 *$ & $.21 *$ & $.24 *$ \\
\hline I discuss issues with the professor & -.02 & .00 & .02 \\
\hline $\begin{array}{l}\text { I meet with the professor in informal } \\
\text { settings }\end{array}$ & -.03 & -.06 & .02 \\
\hline $\begin{array}{l}\text { I obtain feedback from the professor before } \\
\text { I submit an assignment }\end{array}$ & .08 & -.13 & -.01 \\
\hline $\begin{array}{l}\text { My instructor gives me appropriate } \\
\text { coaching }\end{array}$ & .03 & -.01 & .02 \\
\hline Connectedness & .00 & .05 & .00 \\
\hline Rapport 1 & -.02 & -.07 & .03 \\
\hline Rapport 2 & -.06 & .01 & -.09 \\
\hline
\end{tabular}

Connectedness, rapport and participation.

With the same $n=105$ participants, we evaluated the relationship between connectedness, rapport and participation (RQ3). Connectedness and both rapport measures significantly correlate with each other [connectedness and rapport 1: $r(101)=.46, p<.001$; connectedness and rapport 2 : $r(98)=.50, p<.001]$ and with class participation as shown in Table 5. 
Table 5. The relationship between connectedness and rapport measures and in-class participation and out-of-class engagement.

\begin{tabular}{|c|c|c|c|}
\hline & Connectedness & $\begin{array}{l}\text { Rapport } \\
1\end{array}$ & $\begin{array}{l}\text { Rapport } \\
2\end{array}$ \\
\hline $\begin{array}{l}\text { How frequently did you participate in class } \\
\text { this semester? }\end{array}$ & $.36^{* *}$ & $.33^{*}$ & $.37 * *$ \\
\hline $\begin{array}{l}\text { I see the professors with questions/ } \\
\text { problems }\end{array}$ & $.35 * *$ & $.21 *$ & $.31 * *$ \\
\hline I exchange e-mail with the professor & .18 & $.35^{*}$ & $.28 * *$ \\
\hline I discuss issues with the professor & .08 & $.29 * *$ & .14 \\
\hline $\begin{array}{l}\text { I meet with the professor in informal } \\
\text { settings }\end{array}$ & .15 & $.36^{* *}$ & $.22 * *$ \\
\hline $\begin{array}{l}\text { I obtain feedback from the professor before } \\
\text { I submit an assignment }\end{array}$ & $.23^{*}$ & .14 & .17 \\
\hline $\begin{array}{l}\text { My instructor gives me appropriate } \\
\text { coaching }\end{array}$ & $.48 * *$ & $.45^{* *}$ & $.37 * *$ \\
\hline
\end{tabular}

Rapport and connectedness as moderating variables.

A series of hierarchical regression analyses were computed to examine whether rapport and connectedness moderate the association between gender type and in- or out-of-class participation. In each of the models, either in-class or out-of-class participation was the dependent variable. For out-of-class participation, an average of all out-of-class variables was used. In the first step of the model, gender (either masculinity, femininity or androgyny) was entered. Biological sex was entered as the second step. Rapport and connectedness were entered as the third step and finally, the interaction variables were entered (e.g., Masculinity X Rapport 1, Masculinity X Rapport 2, Masculinity X Connectedness, Sex X Gender). Separate regression models were conducted for all three gender variables due to multicollinearity.

Table 6 shows the regression models for in-class participation and Table 7 for out-of-class participation. Marginal significance was revealed for gender when analyzing masculinity $(\beta=.38$, $p=.05)$ and androgyny data $(\beta=.19, p=.11)$. Sex and connectedness was also significant for all three gender variables (see Table 6). For out-of-class participation, rapport was significant for all three gender variables (see Table 7). There were no significant interactions between rapport and connectedness and our three gender variables when using either in-class or out-of-class participation as the dependent measure. Based on these data it appears that rapport and connectedness did not moderate the relationship between gender and participation. Rapport contributes significant variance to out-of-class interactions and connectedness to in-class participation. 
Table 6. Hierarchical linear regression with in-class participation as dependent variable for each gender variable.

\begin{tabular}{|c|c|c|c|c|c|c|c|c|c|c|c|c|c|c|c|}
\hline & \multicolumn{5}{|c|}{ Masculinity } & \multicolumn{5}{|c|}{ Femininity } & \multicolumn{5}{|c|}{ Androgyny } \\
\hline & $\mathrm{R}^{2}$ & $B$ & $S E$ & $\beta$ & $p$ & $\mathrm{R}^{2}$ & $B$ & $S E$ & $\beta$ & $p$ & $\mathrm{R}^{2}$ & $B$ & $S E$ & $\beta$ & $p$ \\
\hline Step 1 & .14 & & & & $<.001$ & .01 & & & & .43 & .13 & & & & $<.001$ \\
\hline Gender type & & .38 & .19 & .28 & .051 & & .17 & .23 & .13 & .46 & & .19 & .12 & .25 & .11 \\
\hline Step 2 & .18 & & & & .04 & .06 & & & & .02 & .176 & & & & .02 \\
\hline Sex & & -.36 & .21 & -.15 & .09 & & -.48 & .20 & -.20 & .04 & & -.43 & .21 & -.19 & .04 \\
\hline Step 2 & .33 & & & & $<.001$ & .24 & & & & $<.001$ & .323 & & & & $<.001$ \\
\hline Connectedness & & .03 & .01 & .22 & .04 & & .03 & .02 & .25 & .05 & & .03 & .01 & .21 & .06 \\
\hline Rapport 1 & & .01 & .01 & .12 & .26 & & .01 & .01 & .15 & .20 & & .01 & .10 & .12 & .25 \\
\hline Rapport 2 & & .02 & .02 & .10 & .38 & & .03 & .03 & .15 & .23 & & .02 & .02 & .10 & .36 \\
\hline Step 3 & .35 & & & & .47 & .25 & & & & .90 & .34 & & & & .74 \\
\hline Gender x Connect & & -.01 & .01 & -.08 & .52 & & .00 & .01 & .02 & .85 & & -.00 & .01 & -.05 & .72 \\
\hline Gender x Rapport 1 & & .02 & .01 & .15 & .15 & & -.01 & .01 & -.04 & .70 & & .01 & .01 & .11 & .37 \\
\hline Gender x Rapport 2 & & .02 & .03 & .08 & .08 & & -.02 & .03 & -.08 & .51 & & .01 & .02 & .06 & .69 \\
\hline
\end{tabular}

Note: Data reflect the $\mathrm{B}, \mathrm{SE}$ and $\beta$ from the last step in the regression model. 
Table 7. Hierarchical linear regression with out-of-class interaction as dependent variable for each gender variable.

\begin{tabular}{|c|c|c|c|c|c|c|c|c|c|c|c|c|c|c|c|}
\hline & \multicolumn{5}{|c|}{ Masculinity } & \multicolumn{5}{|c|}{ Femininity } & \multicolumn{5}{|c|}{ Androgyny } \\
\hline & $\mathrm{R}^{2}$ & $B$ & $S E$ & $\beta$ & $p$ & $\mathrm{R}^{2}$ & $B$ & $S E$ & $\beta$ & $p$ & $\mathrm{R}^{2}$ & $B$ & $S E$ & $\beta$ & $p$ \\
\hline Step 1 & .01 & & & & .40 & .10 & & & & .001 & .02 & & & & .22 \\
\hline Gender type & & -.05 & .12 & -.06 & .70 & & .04 & .12 & .05 & .75 & & -.03 & .07 & -.06 & .70 \\
\hline Step 2 & .02 & & & & .31 & .10 & & & & .76 & .02 & & & & .34 \\
\hline Sex & & .20 & .13 & .14 & .13 & & .15 & .12 & .11 & .23 & & .21 & .13 & .15 & .11 \\
\hline Step 2 & .29 & & & & $<.001$ & .36 & & & & $<.001$ & .29 & & & & $<.001$ \\
\hline Connectedness & & .01 & .01 & .18 & .11 & & .01 & .01 & .16 & .15 & & .01 & .01 & .17 & .13 \\
\hline Rapport 1 & & .02 & .01 & .32 & .00 & & .02 & .01 & .34 & .00 & & .02 & .01 & .33 & .00 \\
\hline Rapport 2 & & .02 & .02 & .14 & .21 & & .02 & .01 & .12 & .26 & & .02 & .02 & .15 & .19 \\
\hline Step 3 & .30 & & & & .76 & .41 & & & & .17 & .32 & & & & .52 \\
\hline Gender x Sex & & .15 & .15 & .15 & .32 & & .29 & .15 & .30 & .05 & & .11 & .09 & .19 & .22 \\
\hline Gender x Connect & & .01 & .01 & .10 & .46 & & .01 & .01 & .11 & .33 & & .00 & .00 & .14 & .30 \\
\hline Gender x Rapport 1 & & -.00 & .01 & -.02 & .83 & & -.01 & .01 & -.07 & .50 & & -.00 & .01 & -.03 & .83 \\
\hline Gender $\mathrm{x}$ Rapport 2 & & -.01 & .02 & -.07 & .63 & & -.01 & .02 & -.07 & .52 & & -.01 & .01 & -.09 & .52 \\
\hline
\end{tabular}

Note: Data reflect the $\mathrm{B}, \mathrm{SE}$ and $\beta$ from the last step in the regression model. 


\section{Discussion}

\section{Student sex, gender and participation}

In our sample, male students reported more in-class participation than female students (RQ1). Although there is inconsistency in the literature (as summarized by Rocca, 2010), there is repeated evidence, including research by Fassinger (1995) conducted on our campus, of greater levels of participation by male students and our findings replicate this. As such, female students could be at a disadvantage in the classroom, especially classrooms that grade participation. This disadvantage maybe particularly salient in science, technology, engineering, and mathematics (STEM) fields. A 2010 report released by the American Association of University Women revealed that between the first year of college and graduation, the rate of women in STEM majors drops drastically despite similar ratios of men and women in elementary, middle, and high school STEM courses. Furthermore, only about $20 \%$ of degrees awarded in some STEM fields (e.g., physics, engineering) are to females (Hill, Cobett, \& St. Rose, 2010). This disparity between men and women in STEM majors may be partially linked to classroom environment. Research has indicated that both male and female STEM professors spend more time interacting with male students (Moss-Racusin, Dovidio, Brescoll, Graham, \& Handelsman, 2012) and call on them more in class (Eddy, Brownell, \& Wenderoth, 2014) perhaps resulting in fewer opportunities for female students to participate. A recent study conducted by Grunspan and colleagues (2016) found that male students disproportionately nominated male peers as being the most knowledgeable about subject matter in an introductory biology class while female students were just as likely to nominate a male or female peer. Another line of research has suggested that female students may underestimate their abilities, particularly in science (Ehrlinger \& Dunning, 2003) while male student may be overconfident of their abilities in STEM fields (Bench, Lench, Liew, Miner, \& Flores, 2015) and these self-assessments might contribute to gender differences in participation. Although the findings of sex difference in participation are inconsistent, the disparities between men and women in STEM classrooms and STEM careers may illustrate one of the consequences of sex differences in participation.

Since the literature on sex differences in class participation are mixed, we sought to evaluate whether psychological gender (masculinity, femininity and androgyny) was related to classroom participation (RQ1). Congruent with findings reported by Pearson and West (1991) we found that students scoring higher on masculinity and androgyny (who also score high on masculine traits) report higher levels of in-class participation. The significant relationship between masculinity and participation could be because classroom participation rewards masculine traits more than feminine traits or possibly because people who are more independent and assertive (traits associated with masculinity) are more likely to participate (see Myers, Martin \& Mottet, 2002 who showed assertiveness was associated with participation). Females are more likely to value interpersonal traits while males are more likely to value instrumental traits (Bennett, 1982). Those instrumental traits, such as assertiveness and confidence, may be more relevant to speaking out in class than interpersonal traits more likely observed in female and feminine students.

Our data also reveal that students with higher scores on feminine and androgynous traits show higher levels of interaction with the professor outside of the classroom. Overall, in our sample, the students scoring higher on androgyny may be more engaged, as measured by oral participation and interactions, both inside and outside of the classroom. When in class, these individuals may use more masculine traits, such as being assertive and dominant, and while outside

Journal of the Scholarship of Teaching and Learning, Vol. 18, No. 4, December 2018. josotl.indiana.edu 
of class, when interacting with their professor, they may use more feminine traits, such as being friendly and warm. In short, the more a student is androgynous, the more adaptable they may be inside and outside of the classroom and this may be one more instance where androgynous individuals have advantage over masculine or feminine individuals. Acknowledging this advantage, The Gender and Communication Handbook, recommends an "androgynous communication style to maximize flexibility and leadership" (Nelson \& Brown, 2012, p. 246).

While our correlations between psychological gender and participation were generally small $(<0.3)$, our data indicate that gender type influences the context in which students participate in their educational experiences. This necessitates questions about how we can make in-class and out-of-class interactions more appealing for all gender types. Based on our findings, limiting a student's participation grade to how much $\mathrm{s} / \mathrm{he}$ talks in class puts feminine individuals at a disadvantage and we recommend that if professors grade participation, they broadly consider participation variables to include more than just speaking up in class. Other variables to include are out-of-class interactions with the professor as well as nonverbal behaviors. Recently published research has shown that oral participation is only weakly correlated with student engagement (Frymier \& Houser, 2016), so perhaps instructors need to reconsider the value of grading participation in general. But, whether or not participation is directly related to engagement, there is value in encouraging and facilitating students' contribution to class; learning to ask questions and share opinions are important skills that contribute to intellectual and cognitive development (Fassinger, 1995; Pearson \& West, 1991). While encouraging such behavior in the classroom is beneficial for students, instructors must be sensitive to gender dynamics that might be at play when contributions are associated with a course grade.

Our study demonstrated gender and sex differences on a self-report in-class participation measure. Although a pilot assessment revealed that student self-report was highly correlated with actual participation, we used a single item self-report measure of in-class participation which may limit validity of our measure. Future research should incorporate additional measures of participation, perhaps using the 7-item measure employed by Frymier \& Houser (2016).

\section{Rapport and connectedness}

Results indicated that both connectedness and rapport were significantly correlated with in-class participation and with various aspects of out-of-class interaction (RQ3), similar to Frisby and Martin (2010) and Sidelinger, Frisby and Heisler (2016). Taken together, these findings underscore the importance of both professor-student rapport and classroom connectedness for student participation and emphasize that by establishing rapport with students and encouraging connectedness among the students professors may cultivate a class environment optimal for student in-class participation and maximize benefits of out-of-class communication with the professor.

Given these findings, professors should be mindful of the characteristics and behaviors that have been identified that promote professor-student rapport (Webb \& Barrett, 2014): (i) uncommonly attentive behaviors, such as knowing the students' names, promptly responding to emails, and striving to involve all students in the class; (ii) connecting behaviors, consisting of the professor being approachable, funny, and informal; (iii) information sharing behaviors, such as communicating clear expectations as well as various nonverbal behaviors (smiling, eye contact); (iv) courteous behaviors, such as creating a supportive and inclusive environment, respecting differing opinions, and being receptive to questions and (v) common grounding behaviors, where

Journal of the Scholarship of Teaching and Learning, Vol. 18, No. 4, December 2018. josotl.indiana.edu 
the professor relates well to the students. Faculty development programs would do well to educate faculty on these rapport-building behaviors if institutions desire faculty to create classroom environments in which students are more likely to participate. In fact, any faculty development programming that focused on student-faculty relationship building would likely benefit the student experience (Linvill, 2014).

Previous research has utilized a single rapport inventory to measure professor-student relationships while the current study used two. The first rapport measure, adapted from Gremler and Gwinner (2000), is widely used and has been validated in previous research. However, this scale focuses more on rapport as a characteristic of the instructor (often affective) and some items lacked specific examples of rapport building behaviors exhibited by professors. Therefore, a supplemental rapport scale was developed using specific behaviors from the five rapport-building categories identified by Webb and Barrett (2014), who coded student responses to open-ended survey questions asking what behaviors their instructors engage in that makes them feel the instructor is building rapport with them. Both rapport measures used in this study correlated with the same participation items except for I discuss various issues with the professor; the Frisby and Myer (2008) rapport measure significantly correlated whereas the measure based on Webb and Barrett (2014) did not. Although, based on our results, there is evidence to suggest that both rapport measures were evaluating the same construct, future research is needed to validate this behaviorally-based rapport measure, given the lower internal consistency score on that measure, and since one rapport measure significantly contributed to variance in out-of-class interactions with the professor, but the other one did not.

\section{Student sex, gender, rapport and connectedness}

Initial findings that gender variables were differently related to in-class participation (RQ1, masculine students reporting higher levels of in-class participation) led us to investigate whether this was moderated by rapport or connectedness (RQ4). On a subset of our data - from participants completing the rapport and connectedness measure - we used a regression analysis to evaluate whether the rapport established by the instructor or student connectedness in the classroom moderated the gender effects. Neither rapport nor connectedness moderated the relationships between gender variables and participation. Based on these data, we suggest that, overall, gender relates to participation independent of the establishment of rapport or connectedness. While these two interpersonal variables (rapport, connectedness) are relevant for creating an environment in which students are active participants, they appear to do so independently of gender. It has been shown that other intrapersonal variables are related to participation (e.g., personality, Capsi et al, 2006, and communication comprehension, Frymier \& Houser, 2016) and these may moderate the relationship between gender and class participation, more so than interpersonal variables.

\section{Professor gender type}

Although student psychological gender was related to participation both in- and outside-of-class, professor gender did not correlate with student participation (RQ2). Fassinger (1995) examined a variety of professor traits and behaviors (categorized into welcomes discussion, approachability and supportiveness) and concluded that none of these were directly related to student participation. While professors are able to influence student participation in the classroom, it appears they do so

Journal of the Scholarship of Teaching and Learning, Vol. 18, No. 4, December 2018. josotl.indiana.edu 
by their behaviors, including course design, rather than intrapersonal characteristics such as gender and personality traits.

As professors design courses and assignments, they should be attentive to their ability to impact student participation; these and other data suggest that regardless of interpersonal traits, professors can create positive classroom environments that encourage participation. Professors, it would seem, should be attentive to their ability to enhance relationships within the classroom. Facilitating interactions between students and between the professor and the students will contribute to an engaged learning space. Additionally, since out-of-class communication has been shown to be associated with affective learning (Dobransky \& Frymier, 2004) and academic outcomes (e.g., higher grades, retention, Wasley, 2006 cited in Frisby \& Martin, 2010) encouraging students to engage with the professor outside of class is important. Finally, in addition to rapport building behaviors being one way to engage students, in her review Rocca (2010) suggests a number of other actions professors can employ to increase student participation, including being a good listener, self-disclosure and use of empathy.

\section{Future directions}

To further evaluate the impact of gender differences, research should explore the relationship between gender type, classroom engagement, and measures of student success, such as course grades and college retention. Using a multiple-item in-class participation measure or observing class participation directly, in addition to employing a course engagement measure (e.g., Handelsman, et al., 2005) would contribute the clarifying the relationships between psychological gender, participation and student engagement. Because our findings showed that context matters when evaluating the effect of gender on participation, we recommend evaluating the relationship between gender and participation in different class contexts, such as on-line versus classroombased course instruction.

\section{Conclusions}

Public scrutiny of higher education demands the faculty attend to student engagement in their teaching and understanding the variables that produce greater levels of student participation are important. This correlational study suggests that intrapersonal variables (e.g., psychological gender) and interpersonal variables (e.g., rapport and connectedness) are of value to classroom participation. Faculty should attend to both as they craft classroom environments meant to encourage participation and engagement.

Given the context of participation (in- or out-of-class) mattered with respect to the gender differences we revealed, faculty should broadly consider participation to include in- and out-ofclass behaviors as they assign participation grades. We also recommend faculty reconsider whether grading oral participation is necessary for a particular course. The consequences of gender and sex biases in the classroom may be minimized if participation is not graded. Rather participation could be encouraged through pedagogical choices and also through building student-faculty rapport and student-student connectedness. We also recommend that institutions provide faculty development opportunities that inform faculty about the importance of inter- and intra-personal variables in student engagement and provide them with tools to develop positive interpersonal interactions in the classroom.

Journal of the Scholarship of Teaching and Learning, Vol. 18, No. 4, December 2018. josotl.indiana.edu 


\section{Acknowledgements}

The authors gratefully acknowledge Dr. Philip Lemaster for assistance with statistical analyses and for making his classroom available for the class participation observational analysis reported in this paper.

\section{References}

Allan, E. J., \& Madden, M. (2006). Chilly classrooms for female undergraduate students: a question of method? The Journal of Higher Education, 77(4), 684-711. doi $10.1353 /$ jhe. 2006.0028

Basow, S. A. (2000). Best and worst professors: Gender patterns in students' choices. Sex Roles, 43(5-6), 407-417. doi:10.1023/A:1026655528055

Basow, S. A., Phelan, J. E., \& Capotosto, L. (2006). Gender patterns in college students' choices of their best and worst professors. Psychology of Women Quarterly, 30(1), 25-35. http://dx.doi.org/10.1111/j.1471-6402.2006.00259.x

Bem, S. L. (1974). The measurement of psychological androgyny. Journal of Consulting and Clinical Psychology, 42(2), 155-162. http://dx.doi.org/10.1037/h0036215

Bench, S. W., Lench, H. C., Liew, J., Miner, K., \& Flores, S. A. (2015). Gender gaps in overestimation of math performance. Sex Roles, 72(11-12), 536546. http://dx.doi.org/10.1007/s11199-015-0486-9

Bennett, S. K. (1982). Student perceptions of and expectations for male and female instructors: Evidence relating to the question of gender bias in teaching evaluation. Journal of Educational Psychology, 74(2), 170-179. doi 10.1037/0022-0663.74.2.170

Canada, K., \& Pringle, R. (1995). The roles of gender in college classroom interactions: A social context approach. Sociology of Education, 68(3), 161-186. http://dx.doi.org/10.2307/2112683

Caspi, A., Chajut, E., Saporta, K., \& Beyth-Marom, R. (2006). The influence of personality on social participation in learning environments. Learning and Individual Differences, 16(2), 129-144. http://dx.doi.org/10.1016/j.lindif.2005.07.003

Crawford, M., \& MacLeod, M. (1990). Gender in the college classroom: An assessment of the for women. Sex Roles, 23(3-4), 101-122. http://dx.doi.org/10.1007/BF00289859

Crombie, G., Pyke, S. W., Silverthorn, N., Jones, A, \& Piccinin, S. (2003). Students' perceptions of their classroom participation and instructor as a function of gender and context. Journal of Higher Education, 74(1), 51-76. http://dx.doi.org/10.1353/jhe.2003.0001

Dancer, D. \& Kamvounias, P. (2005). Student involvement in assessment: a project designed to assess class participation fairly and reliably. Assessment \& Evaluation in Higher Education 30(4), 445-454. http://dx.doi.org/10.1080/02602930500099235

Dobransky, N. D. \& Frymier, A. B. (2004). Developing teacher-student relationships through out of class communication. Communication Quarterly, 52(3), 211-223. doi: 10.1080/01463370409370193

Dwyer. K. K., Bingham, S. G., Calrson, R. E., Prisbell, M., Cruz, A. M., \& Fus, D. A. (2004) Communication and connectedness in the classroom: Development of the connected classroom climate inventory. Communication Research Reports, 21(3), 264-272. http://dx.doi.org/10.1080/08824090409359988 
EAB Daily Briefing. (2016, February). Study correlates liberal arts education with lifelong success. Retrieved from https://www.eab.com/daily-briefing/2016/02/01/study-liberalarts-education-correlated-to-lifelong-success

Eddy S., L., Brownell, S. E., Wenderoth, M. P. (2014). Gender gaps in achievement and participation in multiple introductory biology classrooms. CBE-Life Science Education, 13(3), 478-492. http://dx.doi.org/10.1187/cbe.13-10-0204

Ehrlinger, J., \& Dunning, D. (2003). How chronic self-views influence (and potentially mislead) estimates of performance. Journal of Personality and Social Psychology, 84(1), 5-17. http://dx.doi.org/10.1037/e633872013-215

Fassinger, P.A. (1995). Understanding classroom interaction: Students' and professors' contributions to students' silence. Journal of Higher Education, 66(1), 82-96. https://doi.org/10.2307/2943952

Fassinger, P. A. (2000). How classes influence students' participation in college classrooms. Journal of Classroom Interaction, 35(2), 38-47. http://www.jstor.org/stable/23870446

Fredricks, J. A., Blumenfeld, P. C., \& Paris, A. H. (2004). School engagement: Potential of the concept, state of the evidence. Review of Educational Education, 74(1), 59-109. https://doi.org/10.3102/00346543074001059

Frisby, B. N., \& Myers, S. A. (2008). The relationships among perceived instructor rapport, student participation, and student learning outcomes. Texas Speech Communication Journal, 33, 27-34.

Frisby, B. N., \& Martin, M. M. (2010). Instructor-student and student-student rapport in the classroom. Communication Education, 59(2), 146-164. http://dx.doi.org/10.1080/03634520903564362

Frymier, A. \& Houser, M. L. (2016). The role of oral participation in student engagement. Communication Education, 65(1), 83-104. http://dx.doi.org/10.1080/03634523.2015.1066019

Furnham, A. \& Medhurst, S. (1995). Personality correlates of academic seminar behaviour: A study of four instruments. Personality and Individual Differences, 19(2), 197-208. doi: 10.1016/0191-8869(95)00026-3

Garside, C. (1996). Look who's talking: a comparison of lecture and group discussion teaching strategies in developing critical thinking skills. Communication Education, 45(3), 212-227. http://dx.doi.org/10.1080/03634529609379050

Gremler, D. D., \& Gwinner, K. P. (2000). Customer-employee rapport in service relationships. Journal of Service Research, 3(1) 82-104. http://dx.doi.org/10.1177/109467050031006

Grunspan, D. Z., Eddy, S. L., Brownell, S. E., Wiggins, A., Crowe, J., \& Goodreau, S. M. (2016). Males under-estimate academic performance of their female peers in undergraduate biology classrooms. Plos ONE, 11(2), 1-16. doi: 10.1371/journal.pone.0148405

Handelsman, M. M., Briggs, W. L., Sullivan, N., \& Towler, A. (2005). A measure of college student course engagement. Journal of Educational Research, 98(3), 184-191. http://dx.doi.org/10.3200/joer.98.3.184-192

Hall, R.M. \& Sandler, B.R. (1982). The Classroom Climate: A Chilly One for Women? Washington, DC.: Project on the Status and Education of Women, Association of American Colleges.

Hill, C., Corbett, C., \& St. Rose, A. (2010). Why So Few? Women in Science, Technology, 
Engineering, and Mathematics. Washington DC: American Association of University Women.

Huang, X., Zhu, X., Zheng, J., Zhang, L., \& Shiomi, K. (2012). Relationships among androgyny, self-esteem, and trait coping style of Chinese university students. Social Behavior and Personality, 40(6), 1005-1014. http://dx.doi.org/10.2224/sbp.2012.40.6.1005

Johnson, D. I. (2009). Connected classroom climate: A validity study. Communication Research Reports, 26(2), 146-157. http://dx.doi.org/10.1080/08824090902861622

Jones, R. (2008). The "why" of class participation: A question worth asking. College Teaching, 56(1), 59-63. http://dx.doi.org/10.3200/ctch.56.1.59-64

Junn, E. (1994). Pearls of wisdom: Enhancing student class participation with an innovative exercise. Journal of Instructional Psychology, 21, 385-387.

Kuh (2008), High-Impact Educational Practices: What They Are, Who Has Access to Them, and Why They Matter. Association of American Colleges and Universities, Washington, DC.

Lemaster, P., \& Strough, J. (2014). Beyond Mars and Venus: Understanding gender differences in financial risk tolerance. Journal of Economic Psychology, 42, 148-160. https://doi.org/10.1016/j.joep.2013.11.001

Linvill, D. (2014) Student interest and engagement in the classroom: relationships with student personality and developmental variables. Southern Communication Journal, 79(3), 201214. doi: 10.1080/1041794X.2014.884156

Moss-Racusin, C. A., Dovidio, J. F., Brescoll, V. L., Graham, M. J., Handelsman, J. (2012). Science faculty's subtle gender biases favor male students. Proceedings of the National Academy of Sciences, 109(41), 16474-16479. http://dx.doi.org/10.1073/pnas.1211286109

Myers, S. A., Martin, M. M., \& Mottet, T. P. (2002). Students' motives for communicating with their instructors: Considering instructor socio-communicative style, student sociocommunicative orientations and student gender. Communication Education, 51(2), 121-133. http://dx.doi.org/10.1080/03634520216511

Nelson, A. L. \& Brown, C. D. (2012). The Gender and Communication Handbook. San Francisco, CA: Pfeiffer.

O’Heron, C. A., \& Orlofsky, J. L. (1990). Stereotypic and nonstereotypic sex role trait and behavior orientations, gender identity, and psychological adjustment. Journal of Social and Personality Psychology, 58(1), 134-143. http://dx.doi.org/10.1037/0022-3514.58.1.134

Pearson, J. C., \& West, R. (1991). An initial investigation of the effects of gender on student questions in the classroom: Developing a descriptive base. Communication Education, 40(1), 22-32. http://dx.doi.org/10.1080/03634529109378823

Rocca, K. A. (2010). Student participation in the college classroom: an extended multidisciplinary literature review. Communication Education, 59(2), 185-213. http://dx.doi.org/10.1080/03634520903505936

Sidelinger, R. J., \& Booth-Butterfield, M. (2010). Co-constructing student involvement: an examination of teacher confirmation and student-to-student connectedness in the college classroom. Communication Education, 59(2), 165-184. http://dx.doi.org/10.1080/03634520903390867

Sidelinger, R.J., Frsiby, B.N., \& Heisler, J. (2016). Students' out of the classroom communication with instructors and campus services: Exploring social integration and academic involvement. Learning and Individual Differences, 47, 167-171. http://dx.doi.org/10.1080/03634520302463 
Strough, J., Leszczynski, J. P., Neely, T. L., Flinn, J. A., \& Margrett, J. (2007). From adolescence to later adulthood: Femininity, masculinity, and androgyny in six age groups. Sex Roles, 57(5), 385-396. http://dx.doi.org/10.1007/s11199-007-9282-5

Svanum, S., \& Bigatti, S. M. (2009). Academic course engagement during one semester forecasts college success: engaged students are more likely to earn a degree, do it faster, and do it better. Journal of College Student Development, 50(1), 120-132. http://dx.doi.org/10.1353/csd.0.0055

Waterman, A. S. \& Whitbourne, S. K. (1982). Androgyny and psychosocial development among college students and adults. Journal of Personality, 50(2), 121-133. http://dx.doi.org/10.1111/j.1467-6494.1982.tb01018.x

Weaver, R. R. \& Qi, J. (2005). Classroom organization and participation: College students' perceptions. Journal of Higher Education, 76(5), 570-601. http://dx.doi.org/10.1353/jhe.2005.0038

Webb, N. G., \& Barrett, L. O. (2014). Student views of instructor-student rapport in the college classroom. Journal of the Scholarship of Teaching and Learning, 14(2), 15-28.

doi: 10.14434/josotl.v14i2.4259

Journal of the Scholarship of Teaching and Learning, Vol. 18, No. 4, December 2018.

josotl.indiana.edu 